\title{
Individual's financial investment decision-making in reward-based crowdfunding: Evidence from China
}

\author{
Author Details \\ Author 1 Name: Yasir Shahab \\ Department: Business School \\ University/Institution Affiliated: University of International Business and Economics (UIBE) \\ Town/City: Beijing \\ Country: China \\ Contact Number: +8613126584641 \\ Email Address: roulett360@yahoo.com; DE201465020@uibe.edu.cn; yasirshahab@outlook.com \\ Author 2 Name: Zhiwei Ye \\ Department: Business School \\ University/Institution Affiliated: University of International Business and Economics (UIBE) \\ Town/City: Beijing \\ Country: China \\ Email Address: yzwyzk@163.com \\ Author 3 Name: Yasir Riaz \\ Department: Suleman Dawood School of Business \\ University/Institution: Lahore University of Management Sciences (LUMS), Lahore, Pakistan \\ Town/City: Lahore \\ Country: Pakistan \\ Email Address: $14080001 @$ lums.edu.pk \\ Author 4 Name: Collins G. Ntim \\ Department: Centre for Research in Accounting, Accountability and Governance (CRAAG), \\ Department of Accounting, Southampton Business School \\ University/Institution Affiliated: University of Southampton \\ Town/City: Southampton \\ Country: United Kingdom \\ Email Address: $\underline{\text { C.G.Ntim@ @oton.ac.uk }}$ \\ Corresponding author: Yasir Shahab \\ Corresponding Author's Email: roulett360@yahoo.com; DE201465020@uibe.edu.cn; ; \\ yasirshahab@outlook.com
}




\title{
Individual's financial investment decision-making in reward-based crowdfunding: Evidence from China
}

\begin{abstract}
This paper extends the work of Cecere et al. (Appl. Econ., 49(57): 5802-5813, 2017) and explores the antecedents of backers' decision to invest in projects from eight categories on a reward-based crowdfunding platform in China. We extract data from 2011 to 2016 from the pioneer Chinese reward-based crowdfunding site "Demohour". Our empirical investigation using Ordinary Least Squares (OLS) reveals that feedback score, social capital (followers on Weibo, project sharing on social media) and project quality (number of updates) are key motivating factors in investment decision and subsequently, project success or failure. Robustness tests also confirm the findings.
\end{abstract}

Keywords: Crowdfunding, backers, financial investment decision, online feedback, China.

JEL codes: G19, L19, M13, M21 


\section{Introduction}

With technological advancements, crowdfunding is becoming an imperative source of financing and is receiving extended attention from the economics and finance research community, as well as from entrepreneurs and practitioners. For instance, scholars have examined the role of trust management (Zheng et al., 2016), geographic distance (Kang et al., 2017), multidimensional social capital (Zheng et al., 2017), and factors for success and failure (Abdou et al., 2016, 2017; Mollick, 2014) in reward-based crowdfunding. In more relevant literature, Bi et al. (2017) investigated the impact of online project information on financial investment decisions of reward-based crowdfunding. Similarly, Cecere et al. (2017) examined the role of the pro-social behaviour of funders and find that in non-equity crowdfunding campaigns (i.e., related to film projects in France), altruism is an important decisive factor in making financial and monetary contributions. Colombo et al. (2015) emphasized on the importance of feedback and stressed to probe the role of "constructive feedback" in crowdfunding projects. However, to date existing literature is silent on such examination.

Consequently, we depart from previous studies and mainly contributes to the prevailing literature by investigating the effect of online feedback on the funders' financial investment decision making. We argue that feedback can affect crowdfunding because of three distinct reasons. First, feedback reduces the information asymmetry between the entrepreneurs and crowdfunders. Second, positive (negative) feedback can lure more (less) financial investment from potential backers or customers. Third, constructive feedback can help entrepreneurs fine-tune the overall project based on the feedback received. Thus, feedback from stakeholders can be beneficial for both entrepreneurs and crowd funders and can have direct implication for the success or failure of crowdfunding project.

Further, we argue that 'feedback' can play a significant role in financial investment decision-making, where new investors make financial investment decisions in the presence of information provided or feedback of previous investors or the users of the novel products. Certainly, people respond to the positive or negative comments, reviews and feedback from other individuals while making a purchase/financial investment decision. Such influencing behaviour of reviews and feedback is well-established in the literature in economics, finance and other business and management disciplines as well. For instance, Chua and Banerjee (2016) studied online feedback about digital products (cameras, cell phones and printers) from Amazon and found a significant nexus between the effectiveness of user-generated feedback and information quality across product categories. Similarly, Bond et al. (2012) emphasized that the effect of feedback or information from market prices to the real economy meaningfully alter the comprehension of the process of stock pricing and financial investors' trading behaviour.

Moreover, we extend analysis to 620 projects from eight different project categories from a reward-based crowdfunding platform from the emerging market of China. To the best of our knowledge, this is the first paper to empirically explore the determinants of investors' financial investment decision-making literature from world's second-biggest economy (i.e., China). In the Asia-Pacific region, the Chinese crowdfunding platform is better developed than that of any other country. However, most of the prior literature (see Belleflamme et al. 2014; Kang et al. 2017; Mollick, 2014) has focused on developed nations and have ignored the impact of one important element (i.e., feedback on the ongoing financial investment process). This paper has attempted to fill this research gap by using data from China's biggest reward-based crowdfunding platform (i.e., Demohour). Demohour is the pioneer crowdfunding platform in China, which was introduced in 
2011, where so far, the total funds pledged amount to over 45.5 million RMB against the goal amount of 17.6 million RMB approx. Drawing on a comprehensive dataset of projects launched between 2011 and 2016 on "Demohour" in China, we find feedback score, social capital and project quality as significant determinants of financial investment decisions.

Rest of the paper is structured as follow: Section 2 discusses the data and methodology, and Section 3 presents the results and robustness check, whilst Section 4 provides a conclusion to the paper.

\section{Data and Econometric Methodology}

This study extracts data for 620 projects from "Demohour" between 2011 and 2016 from eight different categories. Previously, Kang et al. (2017) and Zheng et al. (2014) also used "Demohour" (442 and 270 projects) for studying the geographic distance and social capital of backers, respectively. To ascertain our proposed model, we employed following regression equation:

\section{invest $=\mathrm{b}_{0}+\beta_{1}$ Feedback Score $+\beta_{2}$ Controls $+\varepsilon_{1}(1)$}

Invest is an outcome variable equal to the natural log of a number of backers for a project ( $\mathrm{Bi}$ et al. 2017). It represents the number of positive decisions to invest in the project. A greater number of backers represents a greater number of funders who have decided to invest in the project. . Feedback score, social capital and project quality are our predictor variables. Demohour provides an online feedback rating system for customers in three essential strands, namely innovation, design and practicability of the project. Respondents provide feedback on an ordinal scale of zero to five stars on each of the three components. We take average of the three strands to define an integrated feedback response. It ranges from 1 to 5 , where 1 represents the worst feedback and 5 depicting the best feedback. Following Colombo et al. (2015), the model includes the following control variables: (i) the natural log of the number of followers on Weibo; (ii) a dummy variable that is equal to 1 if project is shared on Weibo and 0 otherwise; and (iii) a dummy variable that is equal to 1 if the project is shared on Wechat. Following past studies (Zheng et al., 2014; Zheng et al., 2016), project quality captures: (i) the natural $\log$ of the number of updates about project by owner on Demohour; (ii) a dummy variable that is equal to 1 if shared video(s) on Youku and 0 otherwise; (iii) a dummy variable that is equal to 1 if shared project picture(s) and 0 otherwise. (iv) the goal size (log of the goal amount for the project) (v) duration (time duration of the project) and (vi) project category dummies.

\section{Results}

Descriptive statistics for the full sample are provided in Appendix A. On average, there are 175 backers for each project with average funding of 73,255 RMB. On average, projects have got low ratings (1.85), a good number of regular updates (44) and a time duration of 153 days. The average number of followers is 28 , and average goal amount is $28,450 \mathrm{RMB}$. Appendix B illustrates variance inflation factor (VIF) and correlation values for logbackers against the predictor variables. The values are within the standard threshold for VIF (depicting no issues of multicollinearity) and correlation. Correlation coefficients of logpledged are comparable and available upon request.

Table 1 depicts the effect of predictors on logbackers. Model 1 shows the regression results for control variables only. In all the model (from Models 1 to 8), goal size is found to be a positively and significantly related to logbackers. It is intuitive to say that more contributors are required to 
achieve or collect larger desired goal amount. We first tested the individual effects of our main three predictors on logbackers (i.e., in Models 2 to 4 ) and then we attempted to re-examine the relationship by incorporating two predictors at a time (i.e., in Models 5 to 7 ).

Table 1: Regression results for decision to invest

\begin{tabular}{|c|c|c|c|c|c|c|c|c|}
\hline \multirow[b]{2}{*}{ Predictors } & \multicolumn{8}{|c|}{ Outcome Variable: Logbackers } \\
\hline & Model 1 & Model 2 & Model 3 & Model 4 & Model 5 & Model 6 & Model 7 & Model 8 \\
\hline Feedback & & $\begin{array}{c}0.387 * * * \\
{[0.029]}\end{array}$ & & & $\begin{array}{c}0.225 * * * \\
{[0.028]}\end{array}$ & $\begin{array}{c}0.294 * * * \\
{[0.025]}\end{array}$ & & $\begin{array}{c}0.122 * * * \\
{[0.023]}\end{array}$ \\
\hline $\begin{array}{l}\text { Social } \\
\text { Capital: }\end{array}$ & & & & & & & & \\
\hline Followers & & & $\begin{array}{c}0.453 * * * \\
{[0.040]}\end{array}$ & & $\begin{array}{c}0.310 * * * \\
{[0.040]}\end{array}$ & & $\begin{array}{c}0.487 * * * \\
{[0.026]}\end{array}$ & $\begin{array}{c}0.425^{* * * *} \\
{[0.028]}\end{array}$ \\
\hline wechatSE & & & $\begin{array}{c}0.870 * * * \\
{[0.123]}\end{array}$ & & $\begin{array}{c}0.737 * * * \\
{[0.121]}\end{array}$ & & $\begin{array}{c}0.492 * * * \\
{[0.097]}\end{array}$ & $\begin{array}{c}0.391 * * * \\
{[0.096]}\end{array}$ \\
\hline weiboSE & & & $\begin{array}{c}0.266 * * \\
{[0.111]}\end{array}$ & & $\begin{array}{c}0.296 * * * \\
{[0.110]}\end{array}$ & & $\begin{array}{c}0.196 * * \\
{[0.078]}\end{array}$ & $\begin{array}{c}0.166 * * \\
{[0.079]}\end{array}$ \\
\hline $\begin{array}{l}\text { Project } \\
\text { Quality: }\end{array}$ & & & & & & & & \\
\hline Video & & & & $\begin{array}{c}-0.003 \\
{[0.108]}\end{array}$ & & $\begin{array}{c}0.057 \\
{[0.100]}\end{array}$ & $\begin{array}{c}-0.024 \\
{[0.083]}\end{array}$ & $\begin{array}{c}0.009 \\
{[0.081]}\end{array}$ \\
\hline Images & & & & $\begin{array}{l}-0.017 \\
{[0.101]}\end{array}$ & & $\begin{array}{c}-0.101 \\
{[0.091]}\end{array}$ & $\begin{array}{c}-0.106 \\
{[0.078]}\end{array}$ & $\begin{array}{l}-0.134^{*} \\
{[0.075]}\end{array}$ \\
\hline projectupdates & & & & $\begin{array}{c}0.853 * * * \\
{[0.044]}\end{array}$ & & $\begin{array}{c}0.732 * * * \\
{[0.039]}\end{array}$ & $\begin{array}{c}0.806 * * * \\
{[0.029]}\end{array}$ & $\begin{array}{c}0.765 * * * \\
{[0.029]}\end{array}$ \\
\hline $\begin{array}{l}\text { Control } \\
\text { Variables: }\end{array}$ & & & & & & & & \\
\hline Goalsize & $\begin{array}{c}0.432 * * * \\
{[0.052]}\end{array}$ & $\begin{array}{c}0.361 * * * \\
{[0.047]}\end{array}$ & $\begin{array}{l}0.081 * \\
{[0.046]}\end{array}$ & $\begin{array}{c}0.369 * * * \\
{[0.040]}\end{array}$ & $\begin{array}{c}0.158 * * * \\
{[0.045]}\end{array}$ & $\begin{array}{c}0.313 * * * \\
{[0.038]}\end{array}$ & $\begin{array}{c}0.115 * * * \\
{[0.033]}\end{array}$ & $\begin{array}{c}0.144 * * * \\
{[0.033]}\end{array}$ \\
\hline Duration & $\begin{array}{l}-0.050 \\
{[0.128]}\end{array}$ & $\begin{array}{c}0.116 \\
{[0.122]}\end{array}$ & $\begin{array}{c}-0.031 \\
{[0.119]}\end{array}$ & $\begin{array}{l}-0.052 \\
{[0.102]}\end{array}$ & $\begin{array}{c}0.074 \\
{[0.122]}\end{array}$ & $\begin{array}{c}0.144 \\
{[0.094]}\end{array}$ & $\begin{array}{c}0.013 \\
{[0.080]}\end{array}$ & $\begin{array}{c}0.119 \\
{[0.080]}\end{array}$ \\
\hline Constant & $\begin{array}{c}-0.720 \\
{[0.449]}\end{array}$ & $\begin{array}{c}-0.501 \\
{[0.401]}\end{array}$ & $\begin{array}{c}1.679 * * * \\
{[0.378]}\end{array}$ & $\begin{array}{c}-2.292 * * * \\
{[0.342]}\end{array}$ & $\begin{array}{c}0.959 * * \\
{[0.377]}\end{array}$ & $\begin{array}{c}-1.875^{* * *} \\
{[0.329]}\end{array}$ & $\begin{array}{c}-0.558^{* *} \\
{[0.282]}\end{array}$ & $\begin{array}{c}-0.786 \text { **** } \\
{[0.277]}\end{array}$ \\
\hline $\begin{array}{l}\text { Project } \\
\text { Category }\end{array}$ & Yes & Yes & Yes & Yes & Yes & Yes & Yes & Yes \\
\hline Observations & 586 & 587 & 578 & 583 & 585 & 588 & 582 & 583 \\
\hline R-squared & 0.227 & 0.403 & 0.464 & 0.559 & 0.516 & 0.629 & 0.740 & 0.751 \\
\hline F-Stat & $25.05 * * *$ & $45.29 * * *$ & $38.53 * * *$ & $71.59 * * *$ & $42.68 * * *$ & $85.57 * * *$ & $126.7 * * *$ & $129.9 * * *$ \\
\hline F-Prob & 0 & 0 & 0 & 0 & 0 & 0 & 0 & 0 \\
\hline
\end{tabular}

Robust standard errors in brackets $* * * \mathrm{p}<0.01, * * \mathrm{p}<0.05, * \mathrm{p}<0.1$ 
In Model 8, we integrate all the predictors to check their impact on the logbackers and found the highest $R$-Square (0.751) and significant $F$-Statistic value (129.9) among all the models. Hence, providing support for the proposed model. Feedback score is significant in all models with positive magnitudes. Empirically in the integrative model, $1 \%$ increase in feedback score can be associated with about $0.122 \%$ change in the number of backers.

\subsection{Robustness Checks}

We perform two robustness tests. First, we test for any possible endogeneity between the feedback and investment decision and second, we re-estimate the proposed model using an alternative measure of the dependent variable (i.e., natural log of funds pledged against the goal amount of a project (Belleflamme et al. 2014; Zheng et al. 2014, 2016)). To control for the possible issue of endogeneity (Alhares et al., 2017, 2018; Alnabsha et al., 2018; Elamer et al., 2018; Elmagrhi et al., 2017, 2018; Haque and Ntim, 2018) between the feedback and financial investors' decisions, we employ the technique of Baum et al. (2007) and Wooldridge (2010). To account for this potential issue (Fosu et al., 2017; Nasr and Ntim, 2018; Ntim, 2012, 2013a, b; Shahab et al., 2018; Wang et al., 2015), we re-estimate the model using two-stage least squares (2SLS) technique. The study used 'Project Category wise Mean of the Feedback score' as an instrumental variable for the endogenous variable. Table 2 initially presents the results from $2 S L S$ estimation. The study found comparable findings to the main analysis in Table 1. For the authentication and test strength of the instrumental variable, the under-identification test of "Kleibergen-Paap rk LM statistic" should be significant and "Cragg-Donald Wald F statistic" should be greater than the 10 to depict a strong instrument (Baum et al., 2007). Further, for weak identification test, the "Kleibergen-Paap rk LM statistic" should lie within the 10\% maximal IV size under "Stock-Yogo weak ID test critical values". Table 2 depicts that the endogeneity tests ensure all these benchmarks (particularly the value of F-statistic is 15.837) showing a valid and strong instrumental variable.

Table 2: Robustness Check: Results for endogeneity and alternate proxy of decision to invest

\begin{tabular}{lcccccc}
\hline & $\mathbf{1}^{\text {st }}$ Stage & $\mathbf{2}^{\text {nd }}$ Stage & \multicolumn{3}{c}{ Outcome Variable: Logpledged } \\
\hline Predictors & 2SLS & 2SLS & Model 1 & Model 2 & Model 3 & Model 4 \\
\hline Project category & & & & & & - \\
wise Mean_feedback & $0.495 * * *$ & - & - & - & - & - \\
& {$[0.127]$} & - & - & - & - & - \\
Feedback & - & $0.277^{*}$ & $0.494 * * *$ & - & - & $0.142^{* * *}$ \\
& - & {$[0.168]$} & {$[0.037]$} & - & - & {$[0.030]$} \\
Followers & $0.489 * * *$ & $0.358^{* * *}$ & - & $0.397 * * *$ & - & $0.367^{* * *}$ \\
& {$[0.041]$} & {$[0.088]$} & - & {$[0.056]$} & - & {$[0.035]$} \\
wechatSE & $0.780 * * *$ & 0.230 & - & $1.484 * * *$ & - & $0.841 * * *$ \\
& {$[0.173]$} & {$[0.186]$} & - & {$[0.16]$} & - & {$[0.125]$} \\
weiboSE & -0.153 & $0.196 *$ & - & $0.394 * * *$ & - & $0.210^{* *}$ \\
& {$[0.161]$} & {$[0.104]$} & - & {$[0.15]$} & - & {$[0.106]$} \\
Video & -0.003 & 0.078 & - & - & 0.188 & 0.182 \\
& {$[0.144]$} & {$[0.097]$} & - & - & {$[0.131]$} & {$[0.114]$} \\
Images & 0.061 & -0.115 & - & - & 0.012 & -0.115
\end{tabular}




\begin{tabular}{|c|c|c|c|c|c|c|}
\hline & [0.138] & [0.091] & - & - & [0.121] & [0.099] \\
\hline \multirow[t]{2}{*}{ projectupdates } & $0.282 * * *$ & $0.697 * * *$ & - & - & $1.119 * * *$ & $0.997 * * *$ \\
\hline & {$[0.045]$} & {$[0.070]$} & - & - & {$[0.05]$} & [0.039] \\
\hline \multirow[t]{2}{*}{ Goalsize } & $-0.103 *$ & $0.117 * *$ & $0.626 * * *$ & $0.505 * * *$ & $0.605^{* * *}$ & $0.355^{* * *}$ \\
\hline & {$[0.053]$} & {$[0.045]$} & [0.063] & {$[0.061]$} & {$[0.052]$} & [0.046] \\
\hline \multirow[t]{2}{*}{ Duration } & $-0.298 * *$ & 0.020 & 0.119 & 0.005 & -0.049 & 0.062 \\
\hline & [0.134] & {$[0.110]$} & {$[0.173]$} & [0.172] & [0.137] & {$[0.110]$} \\
\hline \multirow[t]{2}{*}{ Constant } & 0.08 & -0.535 & $1.645 * * *$ & $2.519 * * *$ & -0.676 & $1.179 * * *$ \\
\hline & [0.483] & {$[0.369]$} & {$[0.522]$} & {$[0.503]$} & {$[0.45]$} & {$[0.387]$} \\
\hline Observations & 613 & 613 & 579 & 581 & 577 & 580 \\
\hline Project Category & No & No & Yes & Yes & Yes & Yes \\
\hline R-squared & - & 0.636 & 0.459 & 0.519 & 0.634 & 0.755 \\
\hline F-Stat & - & 150.9 & $57.96 * * *$ & $57.41 * * *$ & $88.60 * * *$ & $124 * * *$ \\
\hline F-Prob & - & 0 & 0 & 0 & 0 & 0 \\
\hline \multicolumn{7}{|l|}{ Under identification tests: } \\
\hline Kleibergen-Paap rk LM statistic & - & 14.592 & - & - & - & - \\
\hline p-value & - & 0 & - & - & - & - \\
\hline \multicolumn{7}{|l|}{ Weak identification tests: } \\
\hline Cragg-Donald Wald F statistic & - & 15.873 & - & - & - & - \\
\hline Kleibergen-Paap rk LM statistic & - & 15.104 & - & - & - & - \\
\hline $\begin{array}{l}\text { Stock-Yogo weak ID test critical } \\
\text { values: } 10 \% \text { maximal IV size }\end{array}$ & - & 16.38 & - & - & - & - \\
\hline
\end{tabular}

Robust standard errors in brackets $* * * \mathrm{p}<0.01, * * \mathrm{p}<0.05, * \mathrm{p}<0.1$

Second, we re-estimate the regression model by replacing logbackers with logpledged in the primary model and found comparable results (see Table 2 from Model 1 to Model 4). This strengthens our findings and depicts robustness in estimations. For brevity, the results are not explained in detail.

\section{Conclusion}

In this paper, we have employed a particular dataset of six years obtained from the pioneer Chinese crowdfunding website to examine the determinants of financial investment decision for reward-based crowdfunding projects. Our examined model is supported by the empirical findings on the basis of regression analysis. Our robust results depict that financial investor's inclination and decision to invest in the reward-based crowdfunding projects is dependent on the feedback of others, social capital and quality of the project.

The findings of this study have exciting insinuations for both backers, entrepreneurs and managers of crowdfunding ventures and platforms. This can be helpful in fostering and developing social connections and appealing funds for both their own and other members' project. First, the study recommends backers to not only rely on their external social capital (e.g., family, friends, followers on Weibo, Wechat, etc. acquaintances), but they should also pay attention to online feedback. They should realize that the consumers of the products/services are the key to the success of their projects. The feedback obtained from the customers can significantly help in post-financial 
investment decision making. It is imperative to build long lasting relationships with the customers, who can become potential investors in future ventures. Further, the originators and entrepreneurs must develop an "interactive customer evaluation," (i.e., rating system while launching the platform). This system must make it obligatory for backers/investors or customers to evaluate the projects and products/services on the basis of standard criteria (as seen on Demohour platform). Such system is lacking in the majority of the crowdfunding platforms. The inclusion of such mandatory evaluation option will enable all the stakeholders (entrepreneurs, project owners, backers, customers and customer-turned investors) to use the component of online feedback in order to make better decision making, and consequently affecting the success/failure of crowdfunding projects.

The project owners need to pay more attention to feedback rating system as the individuals' intention to invest is positively related to online feedback. Further, it is also important for project initiator to increase his/her social circle to attract more financial investors for the project. It is imperative to share these projects or linked them with both WeChat and Weibo in the context of China. Individuals' inclination to invest increases if they find out that their friends have shared projects. Lastly, regarding project quality, the backers put more emphasizes on the regular updates about the projects from project owners. Backers consider updates as the main indicator of the project quality and invest more if more information is provided about projects through regular updates.

\section{References}

Abdou, H.A., Abdallah, W.M., Mulkeen, J., Ntim, C.G., \& Wang, Y. (2017) 'Prediction of financial strength ratings using machine learning and conventional techniques', Investment Management and Financial Innovation, 14(4), 194-211.

Abdou, H., Tsafack, M., Ntim, C.G., and Baker, R. (2016). 'Predicting creditworthiness in retail banking with limited scoring data', Knowledge-Based Systems, 103, 89-103.

Alhares, A. \& Ntim. C.G. (2017). A Cross-Country Study of the Effects of Institutional Ownership on Credit Ratings. International Journal of Business and Management, 12(8), 80-99.

AlHares, A., Ntim, C.G. and King, D. (2018). 'Block Ownership and Companies' R\&D Intensity: The Moderating Effect of Culture', Corporate Ownership \& Control, 15(2), 19-32.

Alnabsha, A.M., Abdou, H., Ntim, C.G., and Elamer, A.A. (2018). 'Corporate Boards, Ownership Structures and Corporate Disclosures: Evidence from a Developing Country', Journal of Applied Accounting Research, 19(1), 20-41.

Baum, C. F., M.E. Schaffer, and S. Stillman. 2007. "Enhanced routines for instrumental variables/GMM estimation and testing." Stata Journal 7(4): 465-506.

Belleflamme, P., T. Lambert, and A. Schwienbacher. 2014. "Crowdfunding: Tapping the right crowd." Journal of Business Venturing 29(5): 585-609.

Bi, S., Z. Liu, and K. Usman. 2017. "The influence of online information on investing decisions of rewardbased crowdfunding." Journal of Business Research 71: 10-18.

Bond, P., A. Edmans, and I. Goldstein. 2012. "The real effects of financial markets." Annual Review of Financial Economics 4(1): 339-360.

Cecere, G., F. Le Guel, and F. Rochelandet. 2017. "Crowdfunding and social influence: an empirical investigation." Applied Economics 49(57): 5802-5813.

Chua, A. Y., and S. Banerjee. 2016. "Helpfulness of user-generated reviews as a function of review sentiment, product type and information quality." Computers in Human Behavior 54: 547-554.

Colombo, M. G., C. Franzoni, and C. Rossi-Lamastra. 2015. "Internal social capital and the attraction of early contributions in crowdfunding." Entrepreneurship Theory and Practice 39(1): 75-100. 
Elamer, A.A., Ntim, C.G. and Abdou, H. (2018). 'Islamic Governance, National Governance and Risk Management and Disclosures Practices in MENA Countries', Business \& Society, [In Press].

Elmagrhi, M.H., Ntim, C.G., Malagila, J., Fosu, S., and Tunyi, A.A. (2018). 'Trustee Diversity, Governance Mechanisms, Capital Structure and Performance in Top UK Charities', Corporate Governance, [In Press].

Elmagrhi, M.H., Ntim, C.G., Crossley, R., Malagila, J., Fosu, S., and Vu, T. (2017). 'Corporate Governance and Dividend Policy in UK Listed SMEs: The Effect of Board Characteristics', International Journal of Accounting and Information Management, 25(4), 459-483.

Elmghaamez, I.B. and Ntim, C.G. (2016). 'Assessing the Effectiveness of Internal Governance Controls: The Case of Internal Auditors Skills and Challenges in Libya', Corporate Ownership and Control, 13(3), 46-58.

Elkhashen, E. and Ntim, C.G., 'Accounting and Philosophy: The Construction of Social Reality Framework', Journal of Accounting and Taxation, [In Press].

Fosu, S., Ntim, C.G., Coffie, W., and Murinde, V. (2017). 'Bank Opacity and Risk-Taking: Evidence from Analysts' Forecasts', Journal of Financial Stability, 33, 81-95.

Haque, F. and Ntim, C.G. (2018). 'Environmental Policy, Sustainable Development, Governance Mechanisms and Environmental Performance', Business Strategy and the Environment, 27, 415435.

Ho, S. Y., and D. Bodoff. 2014. "The effects of Web personalization on user attitude and behavior: An integration of the elaboration likelihood model and consumer search theory." MIS quarterly, 38(2).

Kang, L., Q. Jiang, and C.H. Tan. 2017. "Remarkable advocates: An investigation of geographic distance and social capital for crowdfunding." Information \& Management 54(3): 336-348.

Mollick, E.R. 2014. "The dynamics of crowdfunding: Determinants of success and failure." Journal of Business Venturing 29: 1-16.

Nasr, M. and Ntim, C.G. (2018). 'Corporate Governance Mechanisms and Accounting Conservatism: Evidence from Egypt', Corporate Governance, [In Press].

Ntim, C.G. (2018). Defining Corporate Governance: Shareholder versus Stakeholder Models', in “Global Encyclopedia of Public Administration, Public Policy and Governance", Springer, USA [In Press,

Ntim, C.G. (2012). 'Does the South African Stock Market Values Independent Board Dual Leadership Structure?', Economics and Business Letters, 1(1), 35-45.

Ntim, C.G. (2013a). 'Corporate Ownership and Market Valuation in South Africa: Uncovering the Effects of Shareholdings by Different Groups of Corporate Insiders and Outsiders', International Journal of Business Governance and Ethics, 8(3), 242-264.

Ntim, C.G. (2013b). 'Corporate Governance, Affirmative Action and Firm Value in Post-Apartheid South Africa: A Simultaneous Equation Approach', African Development Review, 25(2), 148-172.

Shahab, Y., Ntim, C.G. and Ullah, F. (2018). 'The Brighter Side of being Socially Responsible: CSR Ratings and Financial Distress among Chinese State and Non-State Owned Firms', Applied Economics Letters, [In Press].

Soobaroyen, T., Broad, M.J., and Ntim, C.G. (2014). 'The Role and Effectiveness of Audit Committees: The Case of UK Higher Education Institutions', Leadership Foundation for Higher Education, London, England, UK

Wooldridge, J. M. 2010. "Econometric analysis of cross section and panel data." MIT press.

Zheng, H., D. Li, J. Wu, and Y. Xu. 2014. "The role of multidimensional social capital in crowdfunding: A comparative study in China and US." Information \& Management 51(4): 488-496.

Zheng, H., J. L. Hung, Z. Qi, and B. Xu. 2016. "The role of trust management in reward-based crowdfunding." Online Information Review 40(1): 97-118.

Wang, Y., Xiaoyu, L., Abdou, H. and Ntim, C. (2015). 'Financial Development and Economic Growth in China', Investment management and Financial Innovations, 12(3), 8-18. 


\section{Appendices}

\section{Appendix A: Descriptive Statistics (Full Sample)}

\begin{tabular}{lccccc}
\hline Variable & N & Mean & $\begin{array}{c}\text { Std. } \\
\text { Dev. }\end{array}$ & $\begin{array}{c}\mathbf{5}^{\text {th }} \\
\text { Percentile }\end{array}$ & $\begin{array}{c}\mathbf{9 5}^{\text {th }} \\
\text { Percentile }\end{array}$ \\
\hline backers & 620 & 174.5032 & 441.5795 & 2 & 671.5 \\
pledged & 620 & 73255.44 & 304997.3 & 98 & 301089 \\
feedback & 620 & 1.853226 & 1.975473 & 0 & 5 \\
followers & 620 & 28.0371 & 123.7626 & 1 & 143 \\
wechatSE & 620 & 0.483871 & 0.500143 & 0 & 1 \\
weiboSE & 620 & 0.277419 & 0.448087 & 0 & 1 \\
Video & 620 & 0.345161 & 0.475805 & 0 & 1 \\
images & 620 & 0.645161 & 0.478851 & 0 & 1 \\
updates & 620 & 44.00484 & 84.82216 & 2 & 148 \\
Goal & 620 & 28452.19 & 116859.3 & 1000 & 100000 \\
duration & 620 & 152.8516 & 157.2033 & 31 & 483 \\
\hline
\end{tabular}

Appendix B: Correlation Matrix and Variance Inflation Factor

\begin{tabular}{|c|c|c|c|c|c|c|c|c|c|c|c|c|}
\hline S.No & Variable & VIF & 1 & 2 & 3 & 4 & 5 & 6 & 7 & 8 & 9 & 10 \\
\hline 1 & Logbackers & - & 1 & & & & & & & & & \\
\hline 2 & Feedback & 1.52 & $0.48 *$ & 1 & & & & & & & & \\
\hline 3 & Followers & 1.53 & $0.51 *$ & $0.46^{*}$ & 1 & & & & & & & \\
\hline 4 & wechatSE & 1.60 & $0.47 *$ & $0.42 *$ & $0.41^{*}$ & 1 & & & & & & \\
\hline 5 & weiboSE & 1.13 & $0.22 *$ & $0.09 *$ & $0.14 *$ & $0.27 *$ & 1 & & & & & \\
\hline 6 & Video & 1.14 & $0.10 *$ & 0.01 & 0.01 & 0.01 & $0.13^{*}$ & 1 & & & & \\
\hline 7 & Images & 1.01 & -0.03 & 0.02 & 0.02 & 0.02 & -0.01 & 0.04 & 1 & & & \\
\hline 8 & Projectupdates & 1.17 & $0.59 *$ & $0.22 *$ & -0.04 & $0.20 *$ & $0.12 *$ & $0.10 *$ & -0.03 & 1 & & \\
\hline 9 & Goalsize & 1.28 & $0.31 *$ & $0.16^{*}$ & $0.30 *$ & $0.30 *$ & $0.12 *$ & $0.15^{*}$ & 0.01 & $.11 *$ & 1 & \\
\hline 10 & Duration & 1.05 & 0.03 & -0.03 & 0.08 & -0.01 & $0.09 *$ & -0.05 & 0.01 & -0.01 & 0.06 & 1 \\
\hline
\end{tabular}

Note: Significance level is at $5 \%$ i.e. $* \mathrm{p}<0.05$ 